\title{
Upaya Meningkatkan Kompetensi Guru Dalam Penulisan Bentuk Soal Pilihan Ganda Abad 21 Berbasis KKG Semester Dua Tahun Pelajaran 2017/2018 Di SD Negeri 12 Ampenan Melalui Pendampingan Klasikal Dan Individual
}

\author{
Sarbini \\ Kepala SD Negeri 12 Ampenan
}

\begin{abstract}
Abstrak. Tujuan penelitian ini adalah untuk mengetahui sejauh mana efektifitas pelaksanaan Pendampingan klasikal dan individual dalam upaya meningkatkan kompetensi Guru di SD Negeri 12 Ampenan dalam penulisan bentuk soal pilihan ganda. Berdasarkan beberapa kajian pustaka, maka hipotesis tindakan dalam penelitian ini adalah: pelaksanaan pendampingan klasikal dan individu dapat meningkatkan kompetensi Guru diSD Negeri 12 Ampenan dalam penulisan bentuk soal pilihan ganda. Penelitian ini dilaksanakan sebanyak dua siklus, masing-masing siklus satu kali pertemuan melalui tahapan: perencanaan, pelaksanaan, pengamatan dan refleksi. Hasil penelitian pada siklus dua pengamatan kegiatan kepala sekolah diperoleh skor rata-rata 4,67, pengamatan kegiatan guru memperoleh skor rata-rata 4,50 sedangkan hasil kerja individual dalam penulisan soal pilihan ganda memperoleh skor rata-rata 94,40. Indikator keberhasilan untuk pengamatan/observasi $\geq 4,00$ dan nilai kerja individual $\geq 85,00$. Indicator keberhasilan telah terpenuhi. Penelitian Tindakan Sekolah (PTS) dihentikan pada siklus kedua dengan hasil sangat memuaskan. Beberapa kendala/hambatan selama penelitian dapat diatasi dengan baik, sehingga dalam pencapaian indikator dengan cepat terpenuhi. Disarankan kepada kepala sekolah yang lain untuk mengadakan penelitian sejenis dalam upaya meningkatkan kompetensi kepala sekolah yang professional.
\end{abstract}

\section{Kata Kunci : Kompetensi Guru - Pendampingan Klasikal dan Individual}

\section{PENDAHULUAN}

\section{Latar Belakang}

Perangkat penilaian/evaluassi bentuk soal pilihan ganda terdiri atas; 1) kisi-kisi soal, 22) kartu soal, 3) master soal, 4) kunci jawaban, dan 5) kriteria penilaian. Dari kelima item ini yang sangat diperlukan untuk dikuasai oleh guru/guru bidang studi/guru mata pelajaran adalah tata cara penulisan bentuk soal pilihan ganda. Alasannya karena alat ukur yang dianggap praktis dan mampu menjangkau materi pembelajaran secara menyeluruh adalah bentuk soal pilihan ganda.Guru yang professional harus mampu menyusun bentuk soal pilihan ganda tingkat tinggi sesuai dengan tuntutan abad 21.Bentuk soal kategori tingkat tinggi ini diharapkan guru menulis soal dengan alternative jawaban yang mengarah ke jenjang penerapan (C3), analisis (C4), dan analisis/evaluasi (C5/C6).Dengan bentuk soal pilihan ganda tingkat tinggi ini diharapkan intelektual peserta didik untuk berfikir kritis, sistematis, dan inovatif dapat terwujud.
Di SD Negeri12 Ampenan secara umum setiap mengadakan ujian semester, ujian tengah semester, dan ulangan harian sudah menggunakan bentuk soal pilihan ganda.Akan tetapi biasanya guru hanya memetik dari soal-soal bentuk pilihan ganda dari LKS terbitan swasta, mengambil dari buku-buku pelajaran tanpa memperhatikan tingkat kesulitan terutama kategori soal tingkat tinggi yang mengarah pada C4, C5, dan C6.

Rendahnya kompetensi guru dalam penulisan bentuk soal pilihan ganda, disebabkan oleh beberapa factor; 1) kebanyakan guru SD Negeri 12 AAmpenan belum pernah mengikuti pendidikan dan pelatihan (Diklat) khusus masalah tata cara penulisan bentuk soal pilihan ganda sesuai dengan kaidah yang berlaku, 2) bimbingan dari kepala sekolah khusus masalah system penilaian terutama tata cara penulisan bentuk soal pilihan ganda secara khusus belum pernah dilakukan, 3) kegiatan Kelompok Kerja Guru (KKG) di sekolah yang khusus 
membahas tentang system penilaian terutama tata cara penulisan bentuk soal pilihan ganda belum pernah dilakukan. Dari ketiga factor penyebab inilah maka kompetensi guru SD Negeri 12 Ampenan dalam penulisan bentuk soal pilihan ganda sesuai dengan kaidah yang berlaku masih rendah.

Banyak solusi yang bias dilakukan oleh peneliti guna meningkatkan kompetensi guru dalam penulisan bentuk soal pilihan ganda khusus bagi guru SD Negeri 12 Ampenan. Salah satu solusinya adalah dengan mengadakan pendampingan klasikal dan individual upaya meningkatkan kompetensi guru SD Negeri 12 Ampenan dalam penulisan bentuk soal pilihan ganda abad 21 sesuai dengan ketentuan yang berlaku. Alas an mengambil tindakan pendampingan ini karena pelakasanaan pendampingan klasikal maupun pendampingan individual memiliki beberapa keunggulan bila dibandingkan dengan model pembimbingan yang lain. Adapun keunggulan-keunggulan pelaksanaan pendampingan klasikal dan individual antara lain; 1) memudahkan bagi kepala sekolah untuk mengidentifikasi kekurangankekurangan guru binaan dalam penulisan bentuk soal pilihan ganada, 2) mudah mencari solusi handal dalam pelaksanaan pendampingan sehingga permasalahan rendahnya kompetensi guru dalam penulisan bentuk soal pilihan ganda dapat diatasi dengan pendampingan klasikal maupun pendampingan individual, 3) pekerjaan yang sulit bias menjadi ringan karena dipecahkan bersama dalam forum KKG dibawah bimbingan/pendampingan kepala sekolah selaku peneliti.

Untuk menjawab wacana diatas maka dipandang perlu diadakan Penelitian Tindakan Sekolah (PTS) bagi kepala SD Negeri 12 Ampenan dengan judul "Upaya Meningkatkan Kompetensi guru Dalam Penulisan Bentuk Soal Pilihan Ganda Abad 21 Berbasis KKG Semester Dua Tahun Pelajaran 2017/2018 Di SD Negeri 12 Ampenan Melalui Pendampingan Klasikal Dan Individual". Judul ini sudah sangat sesuai dengan situasi dan kondisi yang terjadi pada guru/guru mata pelajaran/bidang studi di SD Negeri 12 Ampenan.

\section{Rumusan Masalah}

"apakah pelaksanaan pendampingan klasikal dan individual dapat meningkatkan kompetensi gurudalam penulisan bentuk soal pilihan gandaSemester DuaTahun Pelajaran 2017/2018 di SD Negeri 12 Ampenan? “

\section{Tujuan Penelitian}

untuk mengetahui efektifitas pelaksanaan pendampingan klasikal dan individual upaya meningkatkan kompetensi guru dalam penulisan bentuk soal pilihan gandaSemester DuaTahun Pelajaran 2017/2018 di SD Negeri 12 Ampenan.

\section{Manfaat Penelitian}

- Bagi kepala sekolah : Penelitian ini sangat bermanfaat dalam rangka melaksanakan pendampingan bagi guru di SD Negeri 12 Ampenan dalam penulisan bentuk soal pilihan ganda.

- Bagi guru : Penelitian ini sangat bermanfaat upaya meningkatkan kompetensi dalam penulisan bentuk soal pilihan ganda, sehingga diharapakan menjadi guru yang profesional dibidangnya masing-masing sesuai dengan kelas yang diampunya.

\section{KAJIAN PUSTAKA \\ Kompetensi guru.}

Kompetensi adalah seperangkat pengetahuan, ketrampilan, dan prilaku yang harus dimiliki, dihayati, dan dikuasi oleh guru dan dosen dalam melaksanakan tujuan keprofesionalan. Guru mempunyai kedudukan sebagai tenaga professional pada jenjang pendidikan dasar, menengah dan jenjang pendidikan anak usia dini pada jalur pendidikan formal yang diangkat sesuai dengan peraturan perundang-undangan (UU No. 14 Tahun 2005).

Guru adalah salah satu komponen manusiawi dalam proses belajar mengajar, yang ikut berperan dalam usaha pembentukan sumber daya manusia yang potensial di bidang pembangunan (Sudirman, 1996 : 123). Oleh karena itu guru yang merupakan salah satu unsur dibidang kependidikan harus mampu berperan aktif dan menempatkan dirinya sebagai tenaga professional dan betulbetul professional sesuai dengan tuntutan masyarakat yang semakin berkembang. Guru yang berdedikasi untuk kepentingan pelajar 
tentu tidak akan menuruti kecendrungan modalitasnya di dalam mengajar tetapi akan memperhatikan modalitas pelajarannya di dalam belajar (Suparta-Herry Noer My 2003:168 ). Pendapat ini mengisyaratkan bahwa dalam upaya meningkatkan motivasi dan hasil belajar peserta didik, harus mengidentifikasi karakteristik pendidiknya dalam proses pembelajaran dan dalam menentukan ketuntasan hasil belajar dengan sistem penilaian yang mencerminkan karakteristik peserta didik dan pemberian soal-soal yang berpariasi seperti soal kajian, pilihan ganda, jawab singkat dan penilaian yang bersifat affektif dan psikomotor.

Yang dimaksud dengan kompetensi guru dalam penelitian tindakan sekolah (PTS) ini adalah upaya peningkatan kemampuan Guru dalam penulisan bentuk soal pilihan ganda, di SD Negeri 12 Ampenan yang dilakukan melalui pendampingan yang dilaksanakan secara klasikal maupun kelompok kecil (individual).

\section{Kisi-Kisi dan Soal Pilihan Ganda}

Kisi-kisi dapat didefinisikan sebagai matrik informasi yang dapat dijadikan pedoman untuk menulis dan merakit soal menjadi tes. Dengan menggunakan kisi-kisi, penulis soal akan dapat menghasilkan soal-soal yang sesuai dengan tujuan tes dan perakit tes akan mudah menyusun perangkat tes. Beberapa paket tes yang memiliki tingkat kesulitan, kedalaman materi, dan cakupan materi sama (paralel) akan mudah dihasilkan hanya dengan satu kisi-kisi yang baik. (Depdiknas, $2007: 6$ )

Format kisi-kisi penyusunan soal memuat indentitas kisi-kisis dan matrik spesifikasi rumusan butir soal. Identitas kisikisi minimal memuat nama satuan pendidikan, mata pelajaran/program studi, kurikulum, alokasi waktu, dan jumlah serta bentuk soal, sedangkan matrik spesifikasi setidaknya mencakup kompetensi dasar (KD), materi, kelas/semester, bentuk sola dan nomor soal.

\section{- Bentuk Soal Pilihan Ganda}

Membuat soal memerlukan kecakapan, terutama penguasaan materi, namun belum tentu guru yang menmguasai materi cakap dalam membuat soal, kata-kata tanya apa, siapa, dimana, bilamana, bagaimana, dan mengapa yang diaplikasikan pada metode dan alat penilaian dapat membantunya dalam membuat soal (SupartaHarry Noer, 2003, 235). Membuat soal bentuk pilihan ganda memerlukan pemikiran yang kompleks, hal ini dilakukan dalam upaya menemukan cara terbaik dalam penulisan bentuk soal pilihan ganda, sehingga hasil belajar dan prestasi belajar peserta didik dapat diukur seobyek mungkin tanpa adanya rekayasa dari guru maupun dari pihak lain yang berkaitan dengan prosexs belajar peserta didik.

Soal pilihan ganda dapat diskor dengan mudah, cepat dan memiliki objektivitas yang tinggi, mengukur berbagai tingkatan kognitif, serta dapat mencakup ruang lingkup materi yang luas dalam suatu tes. Bentuk ini sangat tepat digunakan untuk ujian skala besar yang hasilnya harus segera di umumkan, seperti ujian nasional, ujian akhir sekolah, dan ujian seleksi pegawai negeri. Hanya saja, untuk menyususn soal pilihan ganda yang bermutu perlu waktu lama dan biaya cukup besar, disamping itu, penulis soal akan kesulitan membuat pengecoh yang homogen dan berfungsi, terdapat peluang untuk menebak kunci jawaban, dan peserta mudah mencotek kunci jawaban. Secara umum, setiap soal pilihan ganda terdiri dari pokok soal (Stem) dan pilihan jawaban (Option). Pilihan jawaban terdiri atas kunci jawaban dan pengecoh (Distractor).

Dalam penyususnan soal tes tertulis, penulis soal harus memperhatikan kaidahkaidah penyusunan soal dilihat dari segi materi, konstruksi, maupun bahasa. Selain itu soal yang dibuat hendaknya menuuntut penalaran yang tinggi. Hal ini dapat dilakukan antara lain dengan cara : 1) Mengidentifikasi materi yang dapat mengukur perilaku pemahaman, penerapan, analisis, sintesis atau evaluasi. Perilaku ingatan juga diperlukan namun kedudukannya adalah sebagai langkah awal sebelum peserta didik dapat mengukur perilaku yang disebutkan diatas; 2) Membiasakan menulis soal yang mengukur kemampuan berfikir kritis dan mengukur 
ketrampilan pemecahan masalah; dan 3) Menyajikan dasar pertanyaan (stimulan) pada setiap pertanyaan, misalnya dalam bentuk ilustrasi/bahan bacaan seperti kasusu, contoh, tabel dan sebagainya.

\section{Kelompok Kerja Guru (KKG)}

Kelompok Kerja Guru (KKG) adalah wadah kerja sama guru-guru dalam satu gugus, dalam upaya meningkatkan kemampuan profesional mereka. Fungsi utamanya adalah menampung dan memecahkan masalah yang dihadapi dalam KBM melalui pertemuan diskusi, pengajaran contoh, demonstrasi penggunaan dan pembuatan alat peraga. KKG tersebut berorientasi kepada peningkatan kualitas pengetahuan, penguasaan materi, teknik mengajar dan lain-lain yang berfokus pada penciptaan KBM yang efektif. Untuk menunjang kelancaran pelaksanaannya, KKG juga memiliki organisasi kepengurusan, yang terdiri dari Ketua, sekretaris, bendahara, dan anggota. Dibina oleh seorang pengawas serta dibantu oleh beberapa orang guru yang dipandang mempunyai keahlian dalam bidang ilmu tertentu sebagai pemandu bidang studi atau mata pelajaran

Untuk mendapatkan pengakuan sebagai guru yang baik dan berhasil, maka guru berusahalah tampil di muka kelas dengan prima. Setiap guru bertanggung jawab untuk meningkatkan kompotensi profesionalnya. Guru bertanggung jawab secara profesional untuk terus meningkatkan kemampuannya. Dengan demikian, peningkatan kemampuan profesional guru menjadi tugas dan bertanggung jawab guru yang bersangkutan untuk mengupayakannya. Namun demikian tidak semua guru dapat melakukannya secara efektif, oleh karena itu, diperlukan sarana yang dapat menolong mereka. Kelompok kerja guru (KKG) merupakan salah satu sarana atau wadah yang dapat dimanfaatkan guru-guru untuk meningkatkan kemampuan profesionalnya.

\section{Pendampingan Klasikal}

Dalam kamus besar bahasa Indonesia pendampingan/bimbingan artinya memberikan petunjuk/penjelasan cara mengerjakan sesuatu, sedangkan kelompok artinya kumpulan (tentang orang, binatang dll). Pendapat lain mengatakan bahwa pendampingan klasikal merupakan salah satu usaha pemberian bantuan kepada orang-orang yang mengalami masalah (Hartinah, 2009 : 12). Sedangkan kelompok adalah untuk melangsungkan hidupnya karena dengan kelompok manusia dapat memenuhi kebutuhan, mengembangkan diri, mengembangkan potensi serta aktualisasi diri (Yusuf, 1998 : 69 dalam Hartinah, 2009 : 20).

$$
\text { Pendampingan klasikal dalam }
$$

penelitian tindakan sekolah (PTS) ini adalah memberikan petunjuk dan arahan kepada 6 (enam) orangGurudiSD Negeri 12 Ampenan dalam penulisan bentuk soal pilihan ganda sesuai dengan kaidah penulisan bentuk soal pilihan ganda.

\section{Pendampingan Individual}

Pendampingan individual artinya seorang pembimbing menghadapi seorang klien (si terbimbing). Mereka berdiskusi untuk pengembangan diri klien, kemudian merencanakan upaya-upaya bagi diri klien yang terbaik baginya (Sofyan S, 2007 : 15). Ini mengisyaratkan bahwa pelaksanaan pendampingan secara individual/perorangan dilaksanakan dalam bentuk diskusi terhadap permasalahan-permasalahan yang hendak dipecahkan oleh seseorang selanjutnya merencanakan tindakan yang tepat dalam upaya pemecahan permasalahan yang dihadapinya.

Dalam penelitian tindakan sekolah
(PTS) ini yang dimaksud dengan pendampingan individual adalah seorang Kepala Sekolah memberikan arahan, petunjuk dan trik-trik-trik yang tepat kepada 6 (enam) orang Gurudi SD Negeri 12 Ampenan dalam upaya meningkatkan kompetensinya dalam pembuatan kisi-kisi dan penulisan bentuk soal pilihan ganda sesuai dengan kaidah penulisan bentuk soal pilihan ganda. Produktifitas individu dapat dinilai dari apa yang dilakukan oleh individu tersebut dalam kerjanya, yakni bagaimana ia melakukan pekerjaan atau unjuk kerjanya (Mulyasa, 2006 : 74). Dalam penelitian ini yang dimaksud dengan unjuk kerja adalah 6 (enam) Gurudalam penulisan bentuk soal pilihan ganda yang dilakukan secara individu dan terbimbing oleh Kepala Sekolah selaku 
peneliti. Produknya berupa kartu soal pilihan ganda yang sudah diisi dengan baik dan benar sesuai kaidah penulisan bentuk soal pilihan ganda. Dalam pelaksanaan pendampingan individual, peneliti membimbing satu persatu secara bergiliran dalam upaya meningkatkan kompetensinya menyusun bentuk soal pilihan ganda berdasarkan kaidah yang berlaku.

\section{Kerangka Konseptual}

Hubungan antara variabel tindakan dan variabel harapan. Dalam hal ini adalah pelaksanaan pendampingan klasikal dan perorangan dengan kompetensi guru dalam peyusunan soal pilihan ganda. Pelaksanaan bimbingan direncanakan sebanyak 2 (dua) siklus, masing-masing siklus ada satu pertemuan. Pertemuan dilaksanakan pendampingan secara klasikal yang dipusatkan di SD Negeri 12 Ampenan, sedangkan pendampingan secara individual dilaksanakan pada saat kerja kelompok kecil, peneliti membimbing satu persatu secara bergiliran sampai ke 6 (enam) guru secara adil dan merata memperoleh perhatian.

Apabila pada siklus II indikator keberhasilan belum tercapai, maka pendampingan dilanjutkan pada siklus berikutnya tetapi bilamana indikator keberhasilan sudah tercapai maka penelitian dihentikan pada siklus II.

\section{Hipotesis Penelitian.}

"Pelaksanaan pendampingan klasikal dan individual dapat meningkatkan kompetensi gurudi SD Negeri 12 Ampenan dalam penulisan bentuk soal pilihan ganda“.

\section{METODE PENELITIAN}

\section{Jenis Tindakan}

\section{Setting Penelitian}

Penelitian Tindakan Sekolah (PTS) ini dilaksanakan diSD Negeri 12 Ampenan, dengan jumlah peserta 6 (enam) orang Guru yang merupakan tanggung jawab Kepala Sekolah selaku peneliti.

\section{Perencanaan Tindakan}

\section{Jenis tindakan yang dilakukan}

1. Menyampaikan materi yang berkaitan dengan penulisan bentuk soal pilihan gandayang diawali dengan pembuatan kisi-kisi soal. Untuk kisi-kisi soal komponennya terdiri atas : 1) identitas, 2) Standar kompetensi, 3) Kompetensi
Dasar, 4) Kelas/Semester, 5) materi pokok, 6) nomor soal, 7) Rumusan soal, sedangkan kartu soal pilihan ganda komponennya terdiri atas : 1) identitas, 2) Kompetensi Dasar, 3) Materi, 4) Indikator, 5) buku sumber, 6) nomor soal, 7) rumusan butir soal, dan ke 8) kunci jawaban.

2. Skenario pelaksanaannya.

Dalam Penelitian Tindakan Sekolah (PTS) ini, langkah yang akan diambil adalah melalui siklus. Masing-masing siklus menggambarkan proses pendampinganpenulisan bentuk soal pilihan ganda yang diawali dengan pembuatan kisi-kisi soal, sesuai dengan proses pendampingan klasikal dan individual. Adapaun skenario pelaksanaan tindakan dapat digambarkan sebagai berikut:

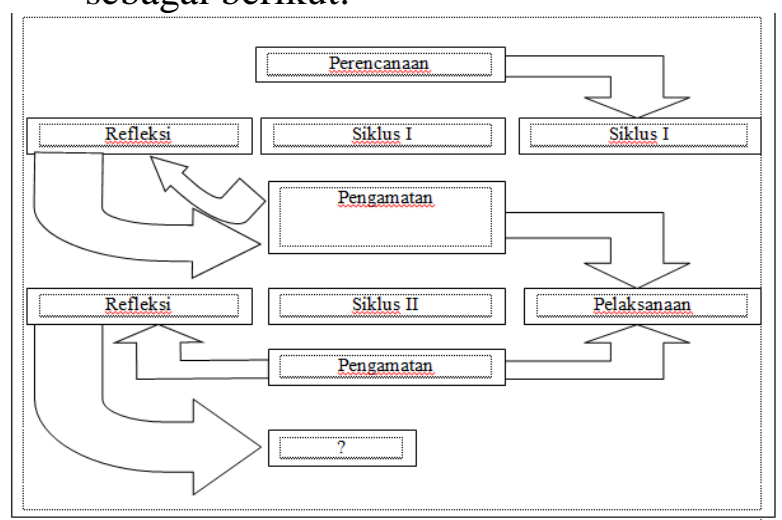

\section{Pelaksanaan Tindakan}

Dalam penelitian ini peneliti melakukan pendampingan penulisan bentuk soal pilihan ganda yang diarahkan dengan penyusunan kisi-kisi soal bagi semua Gurudi SD Negeri 12 Ampenan dengan berpedoman dengan perencanaan yang telah ditetapkan selama proses tindakan disiapkan instrument sebagai berikut :

1. Instrumen observasi Kepala Sekolah yang akan diisi oleh pengawas sekolah selaku observer.

2. Instrument observasi guru peserta pendampingan yang tetap diisi oleh Kepala Sekolah selaku peneliti sekaligus pembimbing dalam penulisan bentuk soal pilihan ganda.

3. Instrument penilaian hasil karya guru dalam penulisan bentuk soal pilihan ganda sesuai dengan kaidah penulisan 
bentuk soal pilihan ganda yang tetap diisi oleh Kepala Sekolah selaku peneliti.

\section{Evaluasi Dan Refleksi Tindakan}

Tahapan ini adalah melakukan kajian dan penilaian proses tindakan dan hasil atau dampak tindakan terhadap perubahan perilaku sasaran (Nana Sudjana, 2009:39). Kegiatan nyatanya adalah; a) membandingkan hasil pengamatan pelaksanaan diskusi yang terfokus pada penulisan bentuk soal pilihan ganda dengan didahului melakukan penyusunan kisi-kisi soal, b) membandingkan hasil kerja individual dengan indikator keberhasilan yang telah ditetapkan.

\section{Siklus Tindakan.}

\section{SIKLUS I}

\section{Tahap I : Perencanaan Tindakan}

1.1. Menyusun materi pendampingan

1.2. Menetapkan scenario dan langkahlangkah pendampingan yang tertuang dalam Rencana Pelaksanaan Pendampingan (RPP)

1.3. Menyusun instrument observasi Kepala Sekolah dan observasi guru

1.4. Menentukan jadwal kegiatan pendampingan

1.5. Menyusun pedoman analisa data hasil observasi dan tugas individu.

Tahap II. Pelaksanaan Tindakan

Tahap I :

2.1. Menyampaikan materi tentang kaidahkaidah penulisan bentuk soal pilihan ganda yang diawali dengan penyusunan kisi-kisi soal.

2.2. Melaksanakan diskusi kelompok hasil penyusunan kisi-kisi dan soal pilihan ganda.

2.3. Memberikan bimbingan secara berkelompok/perorangan.

2.4. Memberikan solusi terhadap permasalahan yang dihadapi oleh guru

2.5. Memberikan penguatan/reward

2.6. Memberikan tugas individual.

\section{Tahap II}

Peneliti melakukan pendampingan secara individual yang dilakukan secara bergiliran, dengan cara peneliti mendatangi gurupada saat kerja dalam kelompok kecil dalam penulisan bentuk soal pilihan ganda.

Tahap III. Pengamatan/pengumpulan Data
3.1. Pengamatan terhadap aktifitas guru peserta pendampingan

3.2. Pengamatan terhadap kinerja guru dalam penulisan bentuk soal pilihan ganda.

3.3. Menilai hasil kerja guru secara individual

\section{Tahap IV. Refleksi}

4.1. Renungan atas data hasil observasi dan hasil kerja secara individual.

4.2. Pengolahan data hasil penelitian

4.3. Rencana perbaikan dan penyempurnaan

4.4. Memberikan penguatan atas hasil yang diperolehnya.

4.5. Rencana tindak lanjut.

\section{SIKLUS II}

Jenis kegiatan pada siklus II ini pada dasarnya sama dengan siklus I, bedanya hanya terjadi perbaikan/penyempurnaan dalam pelaksanaannya.

\section{Indikator Keberhasilan}

- Hasil observasi Kepala Sekolah maupun observasi guru selama proses pendampingan telah memperoleh skor ratarata $\geq 4,0$ (Kategori baik).

- Hasil kerja guru secara individual dalam penulisan bentuk soal pilihan gandaminimal $85 \%$ dari jumlah peserta pendampinganmemperoleh nilai rata-rata $\geq$ 85,00 (kategori tuntas).

\section{HASIL DAN PEMBAHASAN}

\section{Laporan Hasil}

DESKRIPSI SIKLUS I

Perencanaan Tindakan

Peneliti menyiapkan materi pendampingan dalam bentuk power point yang isinya terfokus pada cara penyusunan kisi-kisi soal dan cara penulisan bentuk soal pilihan ganda dengan memperhatikan 16 (enam belas) butir/item sesuai petunjuk dari Departemen Pendidikan Nasional (DEPDIKNAS) tahun 2007 tentang panduan penulisan bentuk soal pilihan ganda. Kegiatan selanjutnya peneliti menyusun Rencana Pelaksanaan Pendampingan (RPP) dengan skenario pendampingan secara klasikal dan pendampingan secara individual. Pada kegiatan pendampingan klasikal peneliti memberikan tugas kepada ke 6 (enam) Gurudengan rincian sebagai berikut: 1) satu kelompok yang beranggotakan 3 (tiga) orang 
guru menyusun kisi-kisi dan soal kelas I, II, Dan III, kelompok yang satu kelas IV, V dan VI.

Jadwal kegiatan pendampingan pada siklus I dilaksanakan pada hari Rabu tanggal 7 Februari 2018 bertempat di SD Negeri 12 Ampenan yang berlangsung dari pukul 09.00 s/d 13.00 wita. Pada tahap pendampingan klasikal peneliti menyampaikan materi tentang tata cara penulisan bentuk soal pilihan gandasesuai kaidah penyusunan soal yang berlaku. pendampingan individual dilaksanakan pada saat peserta bekerja dalam kelompok kecil secara bergiliran semua guru dibimbing satu persatu.

\section{Pelaksanaan Tindakan}

Peneliti mengumpulkan 6 (enam)GuruSD Negeri 12 Ampenan dari pukul 09.00 - 13.00 wita. Pada pertemuan klasikal ini peneliti menyampaikan materi pendampingan dengan berbagai strategi dan metode terkait dengan penyusunan kisi-kisi dan tata cara penulisan bentuk soal pilihan ganda dengan berpedoman pada kaidah penulisan bentuk soal pilihan ganda.

Kegiatan dilanjutkan dengan pelaksanaan diskusi kelompok/kerja kelompok untuk menyusun kisi-kisi soal. Peserta dibagi menjadi 2 (dua) kelompok kecil, masing-masing kelompok beranggotakan 3 (tiga) orang. Kelompok I membuat kisi-kisi dan soal pilihan ganda materi kelas I, II, Dan III, tiap-tiap anggota kelompok membuat 2 (dua) soal sesuai dengan 16 (enam belas) aspek sesuai dengan kaidah penulisan bentuk soal pilihan ganda. Kelompok II membuat kisi-kisi dan soal materi kelas IV, V dan VI.

\section{Pengamatan/Pengumpulan Data}

Hasil observasi kepala sekolah memperoleh skor rata-rata sebesar 3,50, observasi guru memperoleh skor rata-rata sebesar 3,47 dan Hasil kerja individual dalam penulisan bentuk soal pilihan ganda memperoleh nilai rata-rata sebesar 79,88.

\section{Refleksi}

Peneliti merenung atas data hasil observasi maupun data hasil kerja secara individual dalam penulisan bentuk soal pilihan ganda. Pada kegiatan pengamatan guru selama proses pendampingan klasikal maupun individual belum adaguru yang dinyatakan tuntas Selebihnya masih dibawah rata-rata yang diharapkan. Begitu juga dalam perolehan nilai rata-rata hasil kerja individual belum adasatu orang guru pun yang sudah memenuhi indikator keberhasilan.

\section{DESKRIPSI SIKLUS II \\ Perencanaan tindakan}

Pada kesempatan ini peneliti menyiapkan materi pendampingan yang lebih difokuskan pada kegiatan remidi/perbaikan terhadap hasil perolehan pada siklus I, dilanjutkan dengan penajaman materi tentang kaidah penulisan bentuk soal pilihan ganda yang dijelaskan secara rinci disertai dengan pemberian contoh konkrit soal pilihan ganda yang memenuhi syarat sesuai dengan 16 (enam belas) butir kaidah penulisan soal yang baik dan benar. Selanjutnya peneliti membuat skenario pelaksanaan diskusi kelompok dan presentasi hasil kerja kelompok. Kegiatan diatas dikemas dalam bentuk rencana pelaksanaan pendampingan (RPP) yang isinya menggambarkan kegiatan nyata selama proses pendampingan kelompok dan pelaksanaan presentasi hasil kerja kelompok. Hal yang perlu ditegaskan dalam penyusunan RPP ini adalah schedule dan penyesuaian waktu yang telah direncanakan selama proses pendampingan. Kesalahan-kesalahan yang terjadi pada penyusunan RPP pada siklus I diminimalkan dengan mengevaluasi lebih rinci kejanggalan-kejanggalan selama penyusunan RPP pada siklus sebelumnya.

Instrumen observasi kepala sekolah dan instrumen observasi guru masih tetap mengacu pada instrumen yang disusun pada siklus sebelumnya. Penekanannya adalah pada tingkat pemahaman kepala sekolah maupun guru sehingga dalam pelaksanaan proses pendampingan maupun diskusi kelompok lebih optimal. Instrumen penilaian hasil kerja individual dalam penulisan bentuk soal pilihan ganda sama dengan instrumen sebelumnya. Penekannannya adalah tingkat pemahaman peserta pendampingan agar dalam penulisan bentuk soal pilihan ganda pada siklus II ini lebih baik dan kesalahankesalahan yang terjadi pada siklus I agar dapat diminimalkan. 


\section{Pelaksanaan tindakan}

Pelaksanaan tindakan pada siklus II ini tetap dipusatkan di SD Negeri 12 Ampenan pada hari Rabu tanggal 14 Februari 2018 dari pukul 09.00 - 13.00 wita dengan urutan kegiatan sebagai berikut : 1) peneliti mengklarifikasi hasil kerja individual pada siklus I sekaligus diadakan perbaikan dan penyempurnaan sebagaimana yang telah dicantumkan dalam penulisan bentuk soal pilihan ganda sesuai kaidah yang baik dan benar, 2) kegiatan dilanjutkan dengan pemberian tugas yang harus dikerjakan secara individual tetapi pelaksanaannya didiskusikan dengan teman sekelompoknya dibawah pendampingankepala sekolah selaku peneliti, 3) pada saat peserta bekerjasama dalam kelompok peneliti berkeliling mengadakan pengamatan dan pendampingan secara bergiliran, 4) selama proses pendampingan peneliti memberikan penguatan kepada semua guru baik yang mampu mengerjakan tugas dengan cepat dan tepat maupun guru yang mengerjakan tugas agak lamban dan perlu pendampingan khusus, 5) pada akhir pendampingan peneliti mempersilahkan masing-masing kelompok untuk mempersentasikan hasil kerjanya dihadapan peserta secara bergiliran sampai ke 2 kelompok semua tampil mempersentasikan hasil kerjanya.

\section{Pengamatan/pengumpulan data}

Hasil observasi kepala sekolah memperoleh skor rata-rata sebesar 4,67, observasi guru memperoleh skor rata-rata sebesar 4,50 dan Hasil kerja individual dalam penulisan bentuk soal pilihan ganda memperoleh nilai rata-rata sebesar 94,40.

\section{Refleksi}

Hasil renungan terhadap perolehan skor dalam pengamatan maupun perolehan nilai hasil kerja individual dalam penulisan bentuk soal pilihan ganda pada siklus II ini mengalami peningkatan yang tajam dan sangat signifikan. Pada semua data dari instrumen observasi kepala sekolah maupun observasi guru mengalami peningkatan., hal ini disebabkan karena kesalahan-kesalahan yang terjadi pada siklus I telah diminimalkan terutama pada pelaksanaan pendampingan secara klasikal maupun pendampingan secara individual.

Karena indikator keberhasilan telah tercapai maka Penelitian Tindakan Sekolah (PTS) dihentikan pada siklus II dengan hasil sangat memuaskan. Selanjutnya peneliti segera membuat draf penyusunan laporan terhadap apa yang telah dilakukan selama penelitian dari kegiatan perencanaan sampai hasil akhir dari seluruh kegiatan penelitian ini. Secara rinci, sederhana, dan mudah difahami oleh semua pihak yang berkepentingan dengan penelitian ini.

\section{Pembahasan}

\section{SIKLUS I}

\section{Perencanaan tindakan}

Peneliti telah menyiapkan semua materi yang berhubungan dengan pendampingan penulisan soal pilihan ganda, menyusun Rencana Pelaksanaan Pendampingan (RPP) tentang scenario pendampingan penulisan soal pilihan ganda, menyusun instrument observasi kepala sekolah dan observasi guru, ada kendala yang dihadapi dalam tahapan ini. Solusi yang dilakukan yaitu dengan menelaah ulang maksud dan tujuan diadakan penelitian tindakan sekolah (PTS) sebagaimana yang telah dituliskan dalam proposal.

\section{Pelaksanaan Tindakan}

Pada pelaksanaan pendampingan secara klasikal dan individual yang dimulai pukul 09.00 sampai pukul 13.00 wita terpusat di SD Negeri 12 Ampenan bisa berjalan tetapi tidak sesuai dengan waktu yang telah direncanakan, penyebabnya adalah ketika pendampingan dimulai tepat pukul 09.00 masih ada peserta yang belum hadir. Solusinya peneliti terpaksa mengulang materi pendampingan secara sepintas agar peserta yang terlambat hadir mengetahui isi materi pendampingan. Hasilnya semua materi telah disampaikan kepada semua peserta pendampingan.

Pada saat pelaksanaan diskusi kelompok yang membahas tentang penyusunan kisi-kisi soal dan dilanjutkan dengan penulisan bentuk soal pilihan ganda sesuai dengan kaidah penulisan yang baik dan benar, terdapat kendala yaitu masih ada beberap peserta yang bingung tidak tahu apa 
yang harus dikerjakan. Factor penyebabnya karena tingkat pemahaman guru tidak merata, ada yang lansung memahami dan ada yang masih lamban menerima tugas yang harus dilakukan yang berdampak molornya kegiatan. Solusinya peneliti menjelaskan pelan-pelan tugas apa yang harus dikerjakan secara individual oleh guru peserta pendampingan. Hasilnya semua guru telah memahami apa yang harus dilakukan selama proses kerja kelompok dan kerja individual dalam kelompok kerja masing-masing.

\section{Pengamatan/pengumpulan data}

Hasil observasi kepala sekolah diperoleh skor rata-rata $(3,50)$, sementara indikator kinerja mengharapkan mendapat skor rata-rata $(\geq 4,00)$, sementara perolehan skor rata-rata observasi guru adalah $(3,47)$. Ini artinya belum memenuhi indikator keberhasilan yang diharapkan yaitu $(\geq 4,00)$. Sedangkan hasil kerja secara individual dalam penulisan bentuk soal pilihan ganda yang sesuai kaidah penulisan bentuk soal pilihan ganda berbasis HOTS di peroleh nilai ratarata adalah $(79,88)$, sementara indikator keberhasilan proses bimbingan individual dinyatakan telah berhasil jika perolehan nilai rata-rata $(\geq 85,00)$.

Hasilnya kepala sekolah bersama guru menyepakati bahwa pada siklus berikutnya akan datang tepat waktu dan akan melakukan diskusi kelompok/ kerja kelompok dengan bersungguh-sungguh sehingga indikator keberhasilan yang telah direncanakan terpenuhi dengan baik.

\section{Refleksi}

Hasil observasi kepala sekolah memperoleh skor rata-rata $(3,50)$ sementara hasil observasi guru memperoleh skor $(3,50)$ dan hasil nilai rata-rata kerja individual dalam penulisan bentuk soal pilihan ganda adalah 79,88 Dari ketiga perolehan data hasil penelitian pada siklus I masih belum memenuhi target indikator keberhasilan yang telah ditetapkan.

Jenis tindakan yang akan dilakukan dalam proses pendampingan secara klasikal antara lain: 1) pengamatan yang berkesinambungan, 2) pendampingan secara klinis, 3) pemanfaatan waktu yang efektif. Sedangkan tindakan nyata yang dilakukan oleh peneliti dalam pendampingan individual antara lain: 1) memperbaiki hasil kerja yang masih belum sempurna, 2) berbicara yang santun selama pendampingan, dan 3) memberikan penguatan yang positif dan bersifat membimbing. Tindakan nyata itu perlu dilakukan dalam upaya meningkatkan kompetensi gurudan kelas rendah di SD Negeri 12 Ampenan demi terwujudnya system penilaian yang valid dan reliable.

\section{SIKLUS II}

\section{Perencanaan Tindakan}

Tahap awal yang dilakukan oleh peneliti adalah membuat perencanaan refleksi hasil perolehan data pada siklus I yang disampaikan di depan seluruh guru peserta pendampingan. Dalam kegiatan ini peneliti tidak mengalami kendala, semua berjalan lancar. Aspek-aspek yang merupakan kesalahan guru dalam mengerjakan tugas individual diperbaiki dan disempurnakan melalui forum Tanya jawab selama penyampaian materi refleksi. Selanjunya peneliti menyusun Rencana Pelaksanaan Pendampingan (RPP) yang terfokus pada rencana pendampingan berkelompok dan bimbingan individual. Pada tahapan ini peneliti juga tidak mengalami kendala, hambatan, dan kesulitan dalam mengemas scenario pendampingan berkelompok dan individual. Penekanan dalam tahapan penyusunan RPP ini adalah schedule pendampingan yang praktis dan sistematik sehingga dapat dilaksanakan dengan baik..

\section{Pelaksanaan Tindakan}

Dalam pelaksanaan bimbingan secara klasikal maupun individual pada siklus II ini diawali dengan kegiatan refleksi perolehan hasil pada siklus I dilanjutkan dengan penyampaian materi pendampingan dan dilanjutkan dengan diskusi kelompok/kerja kelompok penulisan bentuk soal pilihan ganda sesuai dengan kisi-kisi yang telah dibuat terlebih dahulu. Dalam kegiatan ini tidak ada kendala yang berdampak kurang efektifnya pelaksanaan pendampingan dalam kelompok kecil. Setiap kelompok yang beranggotakan 3 (tiga) orang menulis soal pilihan ganda sebanyak 2 (dua) soal materi dari kelas rendah dan kelasmengikuti kisi-kisi yang telah dibuat terlebih dahulu. Pada kegiatan ini peserta 
sudah tidak terlalu memerlukan bimbingan secara khusus karena semua guru sudah semakin memahami dan semakin menguasai trik-trik penulisan bentuk soal pilihan ganda sesuai dengan kaidah penulisan bentuk soal pilihan ganda.

\section{Pengamatan/Pengumpulan Data}

Perolehan hasil observasi kepala sekolah pada siklus II mencapai skor rata-rata $(4,67)$ dari indikator keberhasilan $(\geq 4,00)$, sedangkan hasil observasi guru mencapai skor rata-rata $(4,50)$ dari indikator keberhasilan $(\geq$ $4,00)$ dan hasil nila rata-rata yang dicapai oleh peserta pendampingan penulisan bentuk soal pilihan ganda adalah $(94,41)$ dari indikator keberhasilan $(\geq 85,00)$.

\section{Refleksi}

Hasil pengamatan terhadap kepala sekolah selaku peneliti yang dilakukan oleh observer memperoleh skor rata-rata (4,67 dan indikator keberhasilan $\geq 4,00$, sementara hasil pengamatan terhadap efektifitas guru peserta pendampingan pada kegiatan diskusi kelompok diperoleh skor rata-rata $(4,50)$ dari indikator keberhasilan $\geq 4,00$, sedangkan niali rata-rata hasil kerja secara individual dalam penulisan bentuk soal pilihan ganda adalah $(94,41)$ dari indikator keberhasilan $\geq 85,00$.

Penelitian Tindakan Sekolah (PTS) diakhiri pada siklus II sesuai dengan rencana yang telah di terangkan pada proposal. Halhal yang mengandung nilai positif dan mampu meningkatkan kompetensi guru perlu terus dilakukan dalam rangka perwujudan kepala sekolah yang berkualitas dan memiliki kompetensi dalam pengembangan keprofesian berkelanjutan (PKB).

\section{Kesimpulan.}

Kompetensi guru di SD Negeri 12 Ampenan dalam penulisan bentuk soal pilihan gandaberbasis HOTSyang diawali dengan pembuatan kisi-kisi soal bentuk pilihan ganda dapat ditingkatkan melalui kegiatan pendampingan secara klasikal dan secara individual. Peningkatan kompetensi dimaksud di dukung oleh data hasil penelitian sebagai berikut:

\begin{tabular}{|c|l|c|c|c}
\hline No & \multicolumn{1}{|c|}{ Jenis Kegiatan } & Siklus I & Siklus II & Keterangan \\
\hline 1. & Observasi Kepala sekolah & 3,50 & 4,67 & Meningkat \\
\hline 2. & Observasi Guru & 3,47 & 4,50 & Meningkat \\
\hline 3. & Kerja Individual & 79,88 & 94,40 & Meningkat \\
\hline
\end{tabular}

Pendampingan klasikal dan pendampingan individual sangat efektif dalam upaya meningkatkan kompetensi gurudalam penulisan bentuk soal pilihan ganda, karena didukung oleh data hasil tindakan nyata melalui penelitian tindakan sekolah (PTS). Perkembangan data hasil observasi dari siklus I ke siklus II mengalami peningkatan sehingga indikator keberhasilan dapat terlampaui. Demikian pula perolehan nilai hasil kerja individual pada siklus ke II telah meningkat dan melampaui indikator keberhasilan.

Karena indikator keberhasilan dalam penelitin ini telah tercapai maka penelitian tindakan sekolah (PTS) dengan judul "Upaya Meningkatkan Kompetensi Guru Dalam Penulisan Bentuk Soal Pilihan Ganda Abad 21 Berbasis KKG Semester Dua Tahun Pelajaran 2017/2018 Di SD Negeri 12 Ampenan Melalui Pendampingan Klasikal Dan Individual" dinyatakan "BERHASIL", penelitian dihentikan pada siklus II.

\section{Saran}

Kepala sekolah sejawat, diharapkan untuk mengadakan penelitian yang sama dalam upaya meningkatkan kompetensi guru yang menjadi binaannya terkait dengan tugas dan tanggung jawabnya sebagai guru mata pelajaran. Pelaksanaan penelitian itu diharapkan mengacu pada hasil yang telah diperoleh oleh kepala sekolahSD Negeri 12 Ampenan dalam penulisan bentuk soal pilihan ganda sesuai dengan kaidah penulisan bentuk soal pilihan ganda. Dalam penelitian itu peneliti mengadakan pendampingan secara klasikal maupun secara individual terhadap 6(enam)Gurudi SD Negeri 12 Ampenan..

Kepada Guru yang terlibat dalam penelitian ini agar mampu mengaplikaasikan dalam proses pembelajaran di kelas senyatanya dalam bentuk ulangan harian, ujian tengah semester, ujian semester, maupun ujian sekolah. Selain itu diharapkan guru sebagai peserta pendampingan, pasca mengikuti kegiatan mampu menularkan kepada guru mata pelajaran lain tentang tata cara penulisan bentuk soal pilihan ganda sesuai dengan kaidah penulisan soal yang baik dan benar, didahului dengan penyusunan kisi-kisi soal pilihan ganda. 


\section{DAFTAR PUSTAKA}

Anonim, 2018, dalam https://pgsd.binus.ac.id/2018/11/23/mengint egrasikan-higher-order-of-thinking-skillhots-pada-pembelajaran-sains-di-sdl, pada tanggal 13Januari 2018, pukul 9.55 wita.

Anonim, 2019, tugas dan tanggung jawab KKG, dalam http://infopendidikan17.blogspot.com/2 015/11/pengertian-tugas-dan-tanggungjawab.html, diambil tanggal 16 Januari 2018 pukul 11.36 wita

Arikanto, S, 2006, Penelitian Tindakan Kelas, Jakarta: Bumi Aksara.

Depdiknas, 2007, Panduan Penulisan bentuk soal pilihan ganda, Jakarta: Pusat Penilaian Pendidikan Balitbang.

Depdiknas, 2001, Kamus Besar Bahasa Indonesia, Jakarta: Balai Pustaka.

Hartinah, S, 2009, Konsep Dasar Bimbingan Kelompok, Bandung: Pelita Aditama.

Kementrian Nasional, 2011, Pedoman Kegiatan, Pengembangan Keprofesian Berkelanjutan (PKB), Jakarta: Direktorat Pembinaan Pendidik dan Tenaga Kependidikan Pendidikan Dasar.

ementrian Nasional, 2011, Buku Kerja Kepala sekolah Sekolah, Jakarta: Pusat Pengembangan Tenaga Kependidikan Badan Pengembangan Sumber Daya Manusia Pendidikan Dan Penjamin Mutu Pendidikan.

Nana Sudjana, 2009, Penelitian Tindakan Kekepala sekolahan Konsep Dan Aplikasinya Bagi Kepala sekolah Sekolah, Jakarta: LPP Bina Mitra.

Permendikbud No. 23 Tahun 2016 Tentang Standar Penilaian

Radno Harsanito, 2007, Pengelolaan Kelas Yang Dinamis, Paradigma Baru Pembelajaran Menuju Kompetensi Siswa, Yogyakarta: Kanisius.

Suhardjono, 2006, Penelitian Tindakan Kelas Sebagai Kegiatan Pengembangan Profesi Guru, Jakarta: Bumi Aksara.

Suhardjono, 2009, Melaksanakan Sekolah Sebagai Kegiatan Penelitian Tindakan Sekolah Sebagai Kegiatan
Pengembangan Profesi Kepala sekolah Sekolah, Jakarta: Bumi Aksara.

Suhardjono, dkk, 2012, Publikasi Ilmiah Dalam Kegiatan Pengembangan Keprofesian Berkelanjutan Bagi Guru, Jakarta: Cakrawala Indonesia.

Sardiman, 1996, Interaksi Dan Motivasi Belajar Mengajar Pedoman Bagi Guru Dan Calon Guru, Jakarta: Ocafindo.

Suparta-Harry Noer Aly, 2003, Metodologi Pengajaran Agama Islam, Jakarta: Amisscd.

Sofyans, 2007, Konseling Individual Teori Dan Praktik, Bandung: Alfabeta.

Undang-undang Nomor 11 Tahun 2005 Tentang Guru Dan Dosen.

User Usman, 2001, Menjadi Guru Profesional, Bandung: Remaja Rosda Karya.

Wiriatmadja, 2007, Metode Penelitian Tindakan Sekolah Sebagai Karya Tulis Ilmiah Dalam Kegiatan Pengembangan Profesi Kepala sekolah Sekolah, Jakarta: Dirjen PMPTK 